Article

\title{
Antidiabetic Activity of Cactus Acid Fruit Extracts: Simulated Intestinal Conditions of the Inhibitory Effects on $\alpha$-amylase and $\alpha$-glucosidase
}

\author{
Gabriela Medina-Pérez ${ }^{1,2}$, Ana Karen Zaldívar-Ortega ${ }^{1}$, Antonio de Jesús Cenobio-Galindo ${ }^{1}$, \\ Laura Natali Afanador-Barajas ${ }^{3}{ }^{(1)}$, Rodolfo Vieyra-Alberto $\left.{ }^{1} \mathbb{(}\right)$, José Antonio Estefes-Duarte ${ }^{1}$ and \\ Rafael G. Campos-Montiel ${ }^{1, *(D)}$ \\ 1 Instituto de Ciencias Agropecuarias, Universidad Autónoma del Estado de Hidalgo, Av. Rancho \\ Universitario s/n Km.1, Tulancingo C.P. 43760, Hgo., Mexico; gamepe@yahoo.com (G.M.-P.); \\ nutriologazaldivar@gmail.com (A.K.Z.-O.); anjec_hs@hotmail.com (A.d.J.C.-G.); \\ rodolfo_vieyra@uaeh.edu.mx (R.V.-A.); liltunechi128@gmail.com (J.A.E.-D.) \\ 2 Programa de Doctorado en Desarrollo Científico y Tecnológico para la Sociedad, Centro de Investigación y \\ de Estudios Avanzados del Instituto Politécnico Nacional, Ciudad de México C.P. 07369, Cd. México, Mexico \\ 3 Facultad de Ingeniería y Ciencias Básicas, Departamento de Ciencias Naturales, Universidad Central de \\ Colombia, Carrera 5 \#21-38, C.P. 110311 Bogotá, Colombia; laura.afanador@gmail.com \\ * Correspondence: ragcamposm@gmail.com; Tel.: +52-771-717-2000 (ext. 2122)
}

Received: 26 July 2019; Accepted: 19 September 2019; Published: 29 September 2019

check for updates

Featured Application: Xoconostle has been studied for its nutritional composition, favorable health effects and presence of bioactive compounds. Traditional mexican medicine attributes various properties to this fruit: hypoglycemic, hypocholesterolemic, anti-inflammatory, antiulcerogenic and immunostimulant, among others. Lowering glucose levels is one of the goals in patients diagnosed with diabetes. There are different factors and triggers of the disease which determines pharmacological treatments that can be helped with the use of therapeutic alternatives such as the consumption of natural products. The severity and complications related to diabetes, the increase in cases worldwide of sick people, the lack of resources and the importance of finding new alternatives as a measure of prevention, as well as treatment, justify the research of new alternatives. Based on this precedent, it is important to evaluate the functional properties of the fruit, as well as its mechanism of action since they are still unknown, so there is an interest in conducting more studies to assess its beneficial effects on health.

\begin{abstract}
Acid cactus fruits "xoconostle" have been used since the pre-Columbian period as a treatment against diverse diseases. In this study, bioactive compounds (phenols and flavonoids) and the in vitro inhibition effect against $\alpha$-amylase and $\alpha$-glucosidase were evaluated. Four different extracts of cactus acid fruits were prepared from (1) endocarp, (2) mesocarp, (3) pericarp and (4) whole fruit (WFE). The results showed significant differences $(\mathrm{p}<0.05)$ between extracts. Pericarp extracts had $2.23 \pm 0.01 \mathrm{mg}$ of gallic acid equivalents per gram GAE/g of phenol content and $0.84 \pm 0.14 \mathrm{mg}$ quercetin equivalents per gram QE/g flavonoid content, while WFE presented $1.52 \pm 0.04 \mathrm{mg} \mathrm{GAE} / \mathrm{g}$ and $0.84 \pm 0.14 \mathrm{mg} \mathrm{QE} / \mathrm{g}$; however, the inhibition of $\alpha$-amylase and $\alpha$-glucosidase were higher with WFE. It was found by using $25 \mathrm{mg} / \mathrm{mL}$ of WFE an $\alpha$-amylase inhibition of $63 . \pm 1.53 \%$ and with $30 \mathrm{mg} / \mathrm{mL}$ of WFE an $\alpha$-glucosidase inhibition of $46.5 \pm 1.45 \%$ after simulated intestinal conditions. The WFE could be used as a therapeutic strategy in controlled diets of diabetic patients due to its low cost, natural origin, and effect after simulated intestinal conditions.
\end{abstract}

Keywords: phenols; flavonoids; xoconostle; diabetes mellitus 


\section{Introduction}

In 2018, global statistics showed that the number of people with diabetes mellitus has quadrupled in the past three decades, and this chronic condition is nowadays the ninth major cause of death. About one in 11 adults worldwide now has diabetes mellitus, $90 \%$ of whom have type 2 diabetes mellitus [1]. When the patient in diabetic condition consumes high-calorie meals, could reach extremely high peaks in postprandial glucose and lipids, and these levels can produce inflammation and endothelial dysfunction caused by the generation of reactive oxygen species [2]. Postprandial glucose homeostasis is not only controlled by insulin release but also depends on incretin hormones (glucagon-like peptide-1 and glucose-dependent insulinotropic peptide), and these characteristics make it a difficult metabolic disorder to control [3]. There are several therapeutic strategies for the control of the level of postprandial glucose, such as changes in diet, exercise, and ingestion of oral hypoglycemic drugs (acarbose, miglitol, and voglibose) [4]. In recent years, research on health, nutrition, and foods has been focused on natural origin products whose functionality allows improving and even preventing the increase in glucose levels [3]. The treatment of diabetes can be developed through different approaches, such as inhibiting enzymatic activities, specifically, the inhibition of $\alpha$-glucosidase and $\alpha$-amylase $[5,6]$. Several enzyme inhibitors have been isolated from plants or fruits used as alternative treatments for diabetes mellitus [7-9].

Xoconostle is a reproductive structure (fruit) of prickly pear (Opuntia spp.) [10]. Cactus pear acid fruits have been used for medicinal purposes since the pre-Columbian era for the treatment of various diseases; currently, it is still used in traditional Mexican medicine [11]. There are about fifteen recognized species of xoconostle, but other species producing xoconostle have been found, and they could number 20 or more, all endemic to Mexico, the most commonly used species reported for this purpose include the wild O. joconostle, O. leucotricha, and O. streptacantha, and the cultivated O. ficus-indica Mill and O. matudae Scheinvar $[4,12]$. Cactus acid fruits "xoconostle" are, in general, characterized by high contents of antioxidant compounds, such as ascorbic acid, vitamin E, polyunsaturated fatty acids, phenolic compounds, flavonoids, carotenoids, and betacyanins [12]. The flavonoids can bind to biological polymer enzymes [13] and inhibit $\alpha$-amylase and $\alpha$-glucosidase [14,15]. Several in vitro digestion models have been developed to evaluate the potential inhibitor of bioactive compounds, such as phenols and flavonoids, against digestive carbohydrases [16]. However, to our knowledge, there are no reports of inhibition in vitro assay focused on different parts of the fruit of xoconostle. The objective of this study was to evaluate the potential for enzymatic inhibition of extracts from cactus acid fruit, by applying in vitro assays against two carbohydrases ( $\alpha$-amylase and $\alpha$-glucosidase) in simulated intestinal conditions.

\section{Materials and Methods}

\subsection{Materials}

The cactus acid fruits (xoconostle) variety Ulapa (Opuntia oligacantha C. F. Först.) was harvested in Ulapa Melchor Ocampo, Tetepango, Hidalgo state (altitude $2040 \mathrm{~m}$, latitude $20^{\circ} 08^{\prime} 41.7^{\prime \prime} \mathrm{N}$ longitude $\left.99^{\circ} 09^{\prime} 59.0^{\prime \prime} \mathrm{W}\right)$. Fruits were harvested in physiological maturity state (green pericarp). Fruits were stored at $4{ }^{\circ} \mathrm{C}$ in dark containers until use. Then, fruits were first washed with tap water, and then disinfected by immersion in sodium hypochlorite (commercial bleach $2.5 \%(\mathrm{v} / \mathrm{v})$ ) for $5 \mathrm{~min}$ ), and finally rinse four times with sterile water. This procedure was followed before the processing of fruit to get the four extracts: (1) pericarp, (2) mesocarp, (3) endocarp, and (4) whole fruit (WFE). Enzymes: $\alpha$-amylase, $\alpha$-glucosidase pepsin, pancreatin, and bile salts were purchased from Sigma Aldrich (St. Louis, MO, USA).

\subsection{Extraction of Biocompounds}

Fresh endocarp, mesocarp, pericarp, and whole fruit were extracted, as described by Osorio-Esquivel et al. [17] with slight modifications. One gram samples were shaken with $20 \mathrm{~mL}$ 
methanol and $20 \mathrm{~mL}$ distilled water for $30 \mathrm{~min}$. The mixture was centrifuged at 10,000 rpm for $20 \mathrm{~min}$; the supernatant was placed into a $10 \mathrm{~mL}$ tube. After it was heated to $65^{\circ} \mathrm{C}$ for $60 \mathrm{~min}$ in a water bath for the complete elimination of methanol, it was immediately cooled to room temperature using ice water, and the Cactus Acid Fruit Extracts (CAFE) was obtained. Finally, the extract was stored at $-70{ }^{\circ} \mathrm{C}$.

\subsection{Total Phenolic Content}

Total phenolic content in different extracts was measured by using the Folin-Ciocalteu method, according to Espinosa-Muñoz et al. [18] with some modifications. A $100 \mu \mathrm{L}$ aliquot of the extract was mixed with $500 \mu \mathrm{L}$ of Folin-Ciocalteu (diluted 1:10) and was left still for $7 \mathrm{~min}$. Then, $4 \mathrm{~mL}$ of sodium bicarbonate $(7 \%)$ was added to the mixture, and after that, the mixture was rested for 120 min. Finally, the absorbance was measured at $760 \mathrm{~nm}$ using a spectrophotometer (Jenway 6715 , Staffordshire, ST15 OSA, UK). Results were expressed as milligrams of gallic acid equivalents per gram of fresh weight (mg GAE/g).

\subsection{Total Flavonoids Content}

The determination of total flavonoids was as per Espinosa-Muñoz et al. [18] with some modifications. A solution of aluminum trichloride $\left(\mathrm{AlCl}_{3}\right)$ in $2 \%$ methanol was used. Two milliliters of the extract was mixed with $2 \mathrm{~mL}$ of the methanol solution and placed in the dark to rest for $10 \mathrm{~min}$. The sample was read at a wavelength of $415 \mathrm{~nm}$ using a spectrophotometer (Jenway 6715, Staffordshire, ST15 OSA, UK), the blank was methanol. The results were expressed in milligrams of quercetin equivalents per gram of fresh weight (mg QE/g of sample).

\section{5. $\alpha$-Amylase Inhibition In Vitro Assay}

The determination of $\alpha$-amylase inhibition in aqueous extracts of whole xoconostle fruits was based on the method of Abirami et al. [19] with slight modifications. $100 \mu \mathrm{L}$ of whole fruit extract (WFE) $(5,10,15,20,25,30,35$, and $40 \mathrm{mg} / \mathrm{mL})$ was mixed with $100 \mu \mathrm{L}$ of $0.02 \mathrm{~mol} / \mathrm{L}$ sodium phosphate buffer ( $\mathrm{pH}$ of 6.9) and $100 \mu \mathrm{L}$ of buffer solution of $\alpha$-amylase $(1 \mathrm{U} / \mathrm{mL})$, and it was pre-incubated at $37^{\circ} \mathrm{C}$ for $10 \mathrm{~min}$. After a pre-incubation time, $100 \mu \mathrm{L}$ of aqueous starch solution $(0.1 \%)$ was added and incubated at $37^{\circ} \mathrm{C}$ for $60 \mathrm{~min}$. The reaction was stopped with $1 \mathrm{~mL}$ of dinitrosalicylic acid reagent. The test tubes were then incubated in a water bath set at $90^{\circ} \mathrm{C}$ for $5 \mathrm{~min}$ and immediately cooled to room temperature in an ice bath. The reaction mixture was then diluted after by adding $3 \mathrm{~mL}$ distilled water, and absorbance was measured at $540 \mathrm{~nm}$ using a spectrophotometer (Jenway 6715, Staffordshire, ST15 OSA, UK). A dextrose calibration curve was developed to quantify the amount of reducing sugars obtained as a result of the hydrolysis of starch by the action of $\alpha$-amylase. The results were expressed in the inhibition percentage.

\section{6. $\alpha$-glucosidase Inhibition Assay}

The $\alpha$-glucosidase inhibition assay was performed following Pradeep et al. [20] with slight modifications. $10 \mu \mathrm{L}$ of WFE $(5,10,15,20,25,30,35$, and $40 \mathrm{mg} / \mathrm{mL})$ was mixed with $100 \mu \mathrm{L}$ of sodium phosphate buffer $(0.05 \mathrm{~mol} / \mathrm{L})$ at $\mathrm{pH} 6.9$, and $0.25 \mu \mathrm{L}$ of glucosidase solution $(25 \mathrm{mg} / \mathrm{mL})$ was pre-incubated at $37^{\circ} \mathrm{C}$ for $10 \mathrm{~min}$. Then, $25 \mu \mathrm{L}$ of $3 \mathrm{mM}$ 4-nitrophenyl $\alpha$-D-glucopyranoside (pNPG) substrate was added and incubated at $37^{\circ} \mathrm{C}$ for $40 \mathrm{~min}$. The reaction was terminated by the addition of $25 \mu \mathrm{L}$ of sodium carbonate $(0.1 \mathrm{M})$, and the absorbance was measured at $405 \mathrm{~nm}$. To determine the activity of the $\alpha$-glucosidase enzyme, the amount of $\mathrm{p}$-nitrophenol released during the assay was quantified. Hydrolysis changes from pNPG to pNP were measured by enzyme action. The $\alpha$-glucosidase enzyme hydrolyzes the colorless substrate, producing free p-nitrophenol, which, in an alkaline medium, is transformed into a yellow nitrophenolate ion. The coloration is proportional to the enzymatic activity. The results were expressed in the inhibition percentage. 


\subsection{Simulation Intestinal Conditions}

Simulated gastrointestinal digestion of the WFE was performed following the method described by Ames et al. [21] with some modifications. There were established two phases: (A) Gastric phase; the extract was diluted (1:5) with distilled water and adjusted to $\mathrm{pH} 2$ by addition of $\mathrm{HCl} 6 \mathrm{~N}$ and $20 \mathrm{~mL}$ of gastric liquid ( $16 \%$ of pepsin and $10 \%$ of $\mathrm{NaCl}$ in $\mathrm{HCL} 0.1 \mathrm{M})$. The mix was incubated at $37^{\circ} \mathrm{C}$ for 2 hours in a shaking water bath. When the trial finished, two aliquots were taken for the next step and the further analyses; (B) Second phase; the $\mathrm{pH}$ of samples from the first trial was adjusted to 7 with sodium bicarbonate $(0.5 \mathrm{M})$; then, $1.25 \mathrm{~mL}$ of freshly prepared pancreatin-bile mixture $(0.4 \mathrm{~g}$ of pancreatin and $2.5 \mathrm{~g}$ of bile salts in $100 \mathrm{~mL}$ of $0.1 \mathrm{M} \mathrm{NaHCO}_{3}$ (pancreatic fluid)) was added. The mixture was incubated at $37^{\circ} \mathrm{C}$ for 2 hours in a shaking water bath. When the trial finished, an aliquot was taken for further analysis. At the end of the gastrointestinal digestion, the samples were heated in a boiling bath for $4 \mathrm{~min}$ to inactivate the enzymes and immediately centrifuged at 12,000 rpm for $10 \mathrm{~min}$ at $4{ }^{\circ} \mathrm{C}$ in a centrifuge $\mathrm{Z} 36 \mathrm{HK}$ (HERMLE Labortechnik $\mathrm{GmbH}$, Wehingen, Germany) for the analysis of total phenols, flavonoids, $\alpha$-amylase inhibition, and $\alpha$-glucosidase inhibition.

\subsection{Statistical Analysis}

All experiments were replicated three times. The completely random design was used. All results were expressed as the mean \pm standard deviation of triplicate measurements. When ANOVA had significant differences $(\mathrm{p} \leq 0.05)$, the comparison means technique of Tukey was used. The comparison, between the whole fruit extract (WFE) and whole fruit extract simulated intestinal conditions (WFESCI), was done using student's t-test with significant differences ( $p<0.05)$ (NCSS Software, 2007).

\section{Results and Discussion}

\subsection{Bioactive Compounds}

In this study, significant differences were found $(\mathrm{p}<0.05)$ between the four extracts of cactus fruit (xoconostle).

Results of total phenols and flavonoids contents are presented in Table 1. Higher content of bio-compounds were found in pericarp extract, it had $2.23 \pm 0.01 \mathrm{mg} \mathrm{GAE} / \mathrm{g}$ of phenol and $0.84 \pm 0.14$ $\mathrm{mg} \mathrm{QE} / \mathrm{g}$ flavonoid content, while WFE presented $1.52 \pm 0.04 \mathrm{mg} \mathrm{GAE} / \mathrm{g}$ and $0.84 \pm 0.14 \mathrm{mg} \mathrm{QE} / \mathrm{g}$ in xoconostle variety Ulapa (Opuntia oligacantha C. F. Först). Morales et al. [22] found $59.48 \mathrm{mg} \mathrm{GAE} / \mathrm{g}$ total phenolic content and $58.40 \mathrm{mg}$ QE/g total flavonoids content when they analyzed extracts from seeds of O. matudae fruits, and Osorio-Esquivel et al. [17] found results similar with a different part of Opuntia joconostle fruit. Other authors [12,22] reported similar results with the whole fruit.

Table 1. Total phenolic and flavonoids content in endocarp, mesocarp, pericarp, and whole from cactus acid fruit (xoconostle).

\begin{tabular}{lll}
\hline CAFE of Different Parts & Phenolics (mg GAE/g) & Flavonoids (mg QE/g) \\
\hline Endocarp & $0.98 \pm 0.30^{\mathrm{c}}$ & $0.85 \pm 0.03^{\mathrm{b}}$ \\
Mesocarp & $1.24 \pm 0.02^{\mathrm{b}}$ & $0.27 \pm 0.05^{\mathrm{c}}$ \\
Pericarp & $2.23 \pm 0.01^{\mathrm{a}}$ & $0.84 \pm 0.14^{\mathrm{a}}$ \\
Whole fruit & $1.52 \pm 0.04^{\mathrm{d}}$ & $0.63 \pm 0.07^{\mathrm{d}}$ \\
\hline
\end{tabular}

Cactus Acid Fruit Extracts (CAFE), Gallic Acid Equivalents (GAE), Quercetin Equivalents (QE), the different superscripts of letters in the same column indicates a significant difference $(p<0.05)$ between different parts of the fruit.

In a study conducted by Hernández-Fuentes et al. [12], they concluded that the difference in the total phenolic content could be due to the genotype effect, both of the species and the crops, as well as the growth conditions of the fruits. In nature, there is a wide variety of bioactive compounds that help protect plants against ultraviolet rays and act as a defense against pathogenic microorganisms 
in plants; this protection can also happen in the xoconostle because these fruits can remain several months in the plant if they deteriorate [23]. Bioactive compounds, such as phenolic compounds, act as antioxidants, which delay or prevent oxidation of the substrate, and they are strongly correlated to antioxidant activity. The consumption of xoconostle fruits may contribute to increasing the protective effect of antioxidants in the diet [24].

\subsection{Inhibition Assay of $\alpha$-amylase and $\alpha$-glucosidase}

One of the main enzymes in the human body is $\alpha$-amylase, which is in charge of the hydrolysis of starch, by producing oligosaccharides and disaccharides. Then, $\alpha$-glucosidase hydrolyzes them into monosaccharides to be absorbed in the small intestine, increasing the level of blood glucose a few hours after food intake. Some extract from plants or fruits were reported as $\alpha$-amylase inhibitors. The mechanism of inhibition could be related to the site of carbohydrate-binding and the enzymes, which catalyze the hydrolysis of the internal $\alpha-1,4$ glucosidic linkages in starch [25].

The results of the evaluation of the percentage of inhibition of the four prepared extracts on the activity of $\alpha$-amylase were significantly different $(\mathrm{p}<0.05)$ and are shown in Table 2 . Wang et al. [26] reported the same phenomenon in the inhibition of $\alpha$-amylase in in vitro assay due to the content of anthocyanins of the fruits of cultivated Lycium ruthenicum Murray. WFE extracts had the highest percentage of inhibition of $70 \%$ at $25 \mathrm{mg} / \mathrm{mL}$. Inhibition of the $\alpha$-amylase activity of $90 \%$ was seen with the extract of the leaves of Tamarindus indicia [27]. Pinto et al. [28] found $65 \%$ as the maximum inhibition when it was tested in the Physalis peruviana L. extract. Natural polyphenols have been reported to inhibit the activity of carbohydrate hydrolyzing enzymes like $\alpha$-amylase and $\alpha$-glucosidase [29-32]; however, even pericarp extracts had $2.23 \pm 0.01 \mathrm{mg} \mathrm{GAE} / \mathrm{g}$ of phenol and $0.84 \pm 0.14 \mathrm{mg}$ QE/g flavonoid contents, while WFE presented $1.52 \pm 0.04 \mathrm{mg} \mathrm{GAE} / \mathrm{g}$ and $0.84 \pm 0.14 \mathrm{mg} \mathrm{QE} / \mathrm{g}$. The inhibition of $\alpha$-amylase and $\alpha$-glucosidase was higher in the whole fruit extract.

Table 2. Effect of the extracts from different parts of cactus acid fruit (endocarp, mesocarp, pericarp, and whole fruit) in the inhibition $\alpha$-amylase enzyme.

\begin{tabular}{ccccc}
\hline \multicolumn{5}{c}{$\alpha$-amylase Inhibition (\%) } \\
\hline CAFE mg/mL & Endocarp & Mesocarp & Pericarp & Whole Fruit \\
\hline 5 & $32.19 \pm 0.96^{\mathrm{aA}}$ & $36.72 \pm 2.23^{\mathrm{aB}}$ & $37.97 \pm 1.41^{\mathrm{aB}}$ & $34.77 \pm 0.21^{\mathrm{aA}}$ \\
10 & $43.95 \pm 1.02^{\mathrm{bA}}$ & $48.29 \pm 2.55^{\mathrm{bB}}$ & $43.79 \pm 0.38^{\mathrm{bA}}$ & $49.81 \pm 2.39^{\mathrm{bB}}$ \\
15 & $54.03 \pm 0.18^{\mathrm{cB}}$ & $50.97 \pm 1.79^{\mathrm{bcA}}$ & $56.39 \pm 1.22^{\mathrm{cB}}$ & $5540 \pm 1.08^{\mathrm{cB}}$ \\
20 & $56.06 \pm 0.14^{\mathrm{cA}}$ & $54.01 \pm 1.44^{\mathrm{cA}}$ & $59.05 \pm 1.65^{\mathrm{cdB}}$ & $64.66 \pm 2.59^{\mathrm{dC}}$ \\
25 & $58.38 \pm 0.27^{\mathrm{Da}}$ & $58.65 \pm 1.01^{\mathrm{dA}}$ & $61.46 \pm 2.14^{\mathrm{dA}}$ & $70.40 \pm 1.83^{\mathrm{eB}}$ \\
30 & $60.88 \pm 0.66^{\mathrm{eA}}$ & $59.46 \pm 0.56^{\mathrm{dA}}$ & $66.62 \pm 2.70^{\mathrm{eB}}$ & $72.29 \pm 2.66^{\mathrm{eC}}$ \\
35 & $63.91 \pm 1.07^{\mathrm{Ea}}$ & $62.60 \pm 0.80^{\mathrm{deA}}$ & $67.51 \pm 3.33^{\mathrm{eB}}$ & $72.35 \pm 2.15^{\mathrm{eC}}$ \\
40 & $63.88 \pm 1.80^{\mathrm{Ea}}$ & $63.08 \pm 1.52^{\mathrm{eA}}$ & $67.80 \pm 3.05^{\mathrm{eB}}$ & $71.83 \pm 0.73^{\mathrm{eC}}$ \\
\hline
\end{tabular}

Cactus Acid Fruit Extracts (CAFE). The lowercase letters in columns represent significant differences $(\mathrm{p}<0.05)$ between concentrations of the samples, the capital letters in role indicate significant differences $(p<0.05)$ between the different parts of the fruit.

The results of cactus acid fruit extracts indicate high $\alpha$-glucosidase inhibitory activities with significant differences $(\mathrm{p}<0.05)$. The pericarp and whole fruit extracts showed inhibition percentages of $46.04+2.56 \%$ and $52.11+1.35 \%$, respectively, at the concentration of $30 \mathrm{mg} / \mathrm{mL}$ (Table 3). 
Table 3. Effect of the extracts from different parts of cactus acid fruit (endocarp, mesocarp, pericarp, and whole fruit) in the inhibition $\alpha$-glucosidase enzyme.

\begin{tabular}{ccccc}
\hline \multicolumn{5}{c}{$\alpha$-glucosidase Inhibition (\%) } \\
\hline CAFE mg/mL & Endocarp & Mesocarp & Pericarp & Whole Fruit \\
\hline 5 & $23.62 \pm 2.83^{\mathrm{aA}}$ & $28.58 \pm 2.11^{\mathrm{aB}}$ & $20.06 \pm 2.69^{\mathrm{aA}}$ & $29.17 \pm 0.76^{\mathrm{aB}}$ \\
10 & $23.70 \pm 1.52^{\mathrm{aA}}$ & $28.77 \pm 1.17^{\mathrm{aB}}$ & $21.87 \pm 1.02^{\mathrm{aA}}$ & $29.87 \pm 3.32^{\mathrm{aB}}$ \\
15 & $28.18 \pm 0.08^{\mathrm{bA}}$ & $32.72 \pm 1.23^{\mathrm{bB}}$ & $34.17 \pm 3.02^{\mathrm{bBC}}$ & $36.99 \pm 1.62^{\mathrm{bC}}$ \\
20 & $36.37 \pm 2.45^{\mathrm{cA}}$ & $36.18 \pm 2.25^{\mathrm{bA}}$ & $35.96 \pm 2.51^{\mathrm{bA}}$ & $42.73 \pm 2.10^{\mathrm{cB}}$ \\
25 & $42.66 \pm 3.81^{\mathrm{dA}}$ & $41.70 \pm 0.96^{\mathrm{cA}}$ & $43.10 \pm 0.59^{\mathrm{cAB}}$ & $47.39 \pm 3.82^{\mathrm{dB}}$ \\
30 & $44.29 \pm 1.28^{\mathrm{dB}}$ & $41.31 \pm 1.20^{\mathrm{cA}}$ & $46.04 \pm 2.56^{\mathrm{cB}}$ & $52.11 \pm 1.35^{\mathrm{eBC}}$ \\
35 & $44.56 \pm 2.11^{\mathrm{dB}}$ & $41.19 \pm 1.05^{\mathrm{cA}}$ & $47.42 \pm 1.30^{\mathrm{cC}}$ & $53.28 \pm 1.93^{\mathrm{eD}}$ \\
40 & $45.07 \pm 0.81^{\mathrm{dB}}$ & $41.92 \pm 2.28^{\mathrm{cA}}$ & $46.29 \pm 1.85^{\mathrm{cB}}$ & $54.19 \pm 1.29^{\mathrm{eC}}$ \\
\hline
\end{tabular}

Cactus Acid Fruit Extracts (CAFE) of different parts. The lowercase letters in columns represent significant differences $(p<0.05)$ between concentrations of the samples, the capital letters in role indicate significant differences $(p<0.05)$ between the different parts of the fruit.

Hemalatha et al. [33] observed inhibition effects (91.8\%) in the bran extract. According to Apostolidis et al. [34] and Yin et al. [13], the inhibitory effect of $\alpha$-glucosidase is due to phenols and flavonoids. Inhibitory effects of $\alpha$-glucosidase in the flavonoids quercetin and myricetin were documented by $\mathrm{Xu}$ et al. [14]. Cenobio-Galindo et al. [35] reported that xoconostle fruits contain rutin, ferulic acid, quercetin, 4-hydroxybenzoic acid, apigenin, caffeic acid, and kaempferol, and these phenolic compounds could have an inhibitory effect on $\alpha$-glucosidase. The kaempferol can link with the active site, and thus, the flavonoid can inhibit the enzyme [15].

\subsection{Simulated Digestion In Vitro Assay}

Total phenols (Figure 1A) and flavonoids (Figure 1B) of whole fruit extract (WFE) showed values of bioaccessibility of the $70.4 \%$ and $60.4 \%$, respectively, after simulated intestinal conditions. Bouayed et al. [36] quantified phenols from different varieties of apple and observed accessibility of $60 \%$ after gastrointestinal digestion in vitro.

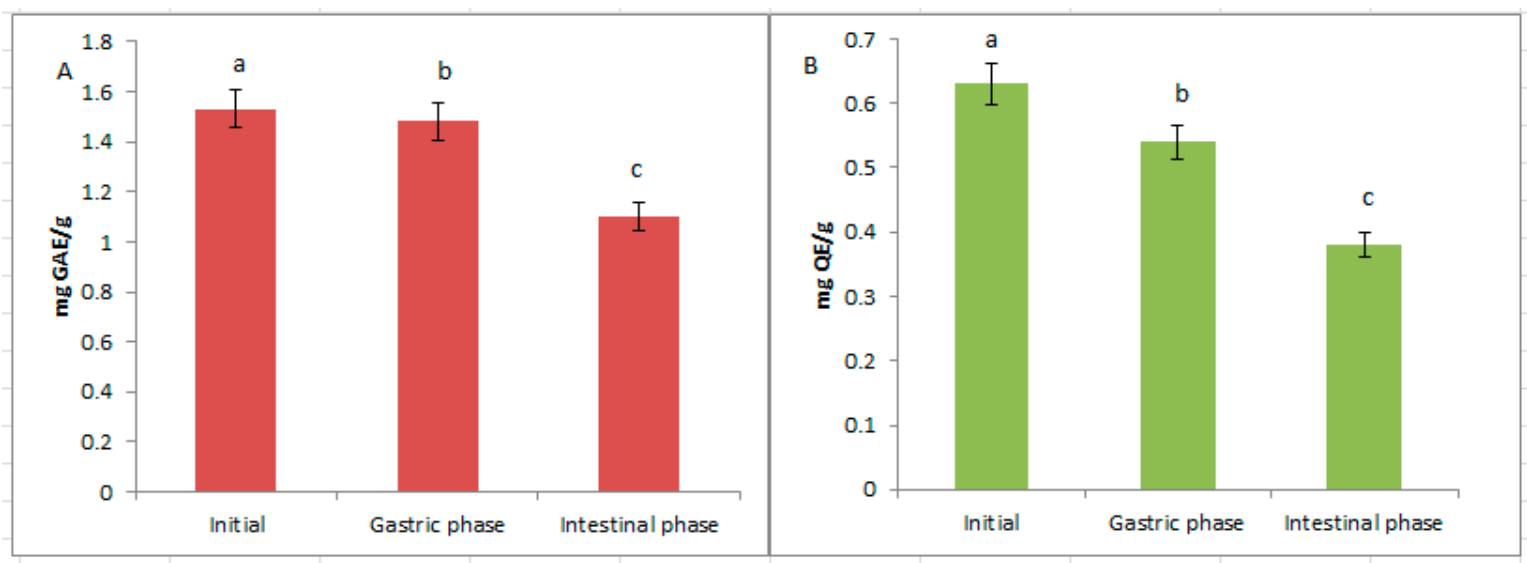

Figure 1. Total phenol content in Xoconostle (Opuntia sp) whole fruit extract (WFE) (A) and Flavonoid in Xoconostle (Opuntia sp) WFE (B) in different phases of simulated intestinal conditions. Values are mean of three replications \pm standard deviation. Different lowercase letters in error bars indicate significant differences $(p<0.05)$ between different phases of simulated intestinal digestion.

The loss of phenolic compounds could be attributed to the chemical conditions because most phenols are sensitive to alkaline conditions, which modify their structures [37]. A reduction of $85 \%$ was observed in flavonoids from the extract of broccoli after intestinal digestion in vitro, and the digestive 
pancreatin enzyme combination can release molecules with the capacity to link with the flavonoids, thus attenuating accessibility [38].

The results of the bioactivity of $\alpha$-amylase of WFE are shown in Figure 2A. The WFE after simulated intestinal conditions (WFESIC) had inhibition of $63.4 \%$ with $25 \mathrm{mg} / \mathrm{mL}$, and it had inhibition of $\alpha$-glucosidase of $46.5 \%$ with $30 \mathrm{mg} / \mathrm{mL}$ (Figure 2B). Spínola et al. [37] reported reduced inhibition of both enzymes from Elaeagnus umbellata and Sambucus lanceolata extracts after gastrointestinal digestion in vitro. The WFESIC has good activity in the inhibition of $\alpha$-amylase and $\alpha$-glucosidase, and these extracts are natural options to control postprandial glycemia and exert antidiabetic effects.

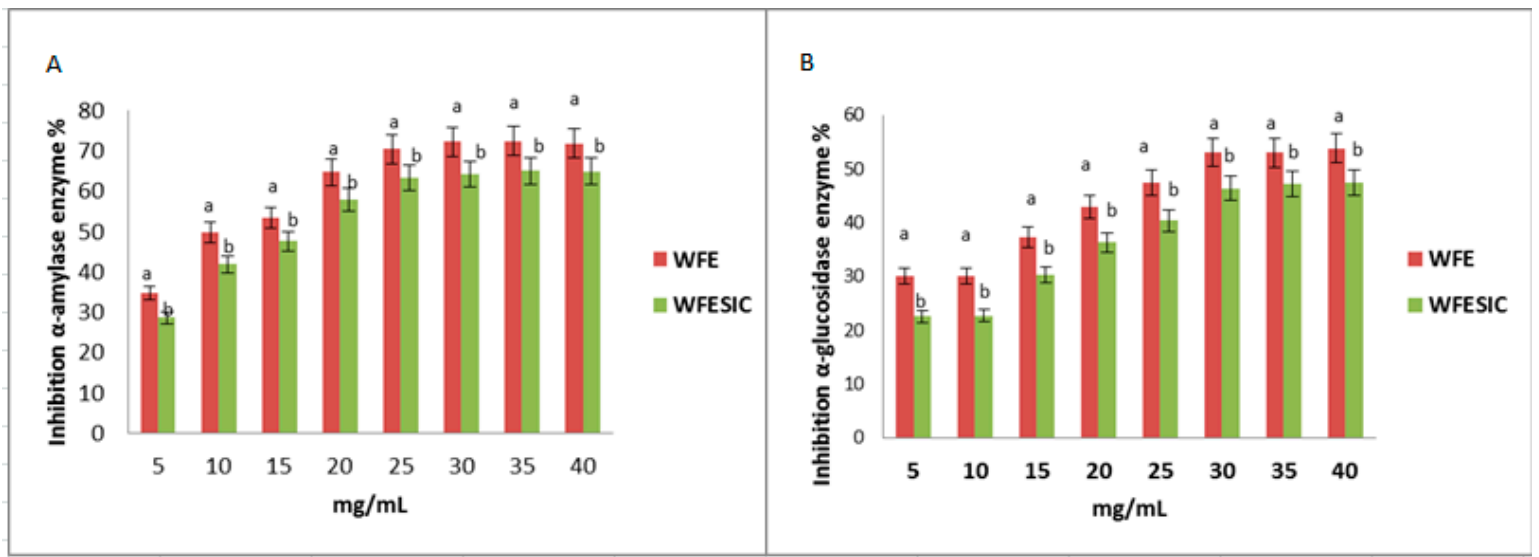

Figure 2. Effect of Inhibition against activity in xoconostle (Opuntia $s p$ ) for (A) $\alpha$-amylase enzyme. (B) $\alpha$-glucosidase enzyme. WFE: Whole Fruit Extract. WFESIC: Whole Fruit Extract simulated intestinal conditions. Values are mean of three replications \pm standard deviation. Different lowercase letters in error bars indicate significant differences $(p<0.05)$ between the WFE and WFESIC in each concentration.

Polyphenol-rich extracts had the ability to inhibit $\alpha$-amylase and $\alpha$-glucosidase. The polyphenolic components of fruits may influence different steps in starch digestion [39].

\section{Conclusions}

The cactus acid fruit (xoconostle) contains bioactive compounds phenols and flavonoids with effective inhibitory activities against key enzymes linked to diabetes mellitus, as shown by $\alpha$-amylase and $\alpha$-glucosidase in vitro assays. The best inhibitory effect of $\alpha$-amylase and $\alpha$-glucosidase was observed for the whole fruit extract with a minimum of 25 and $30 \mathrm{mg} / \mathrm{mL}$, respectively. Bioaccessibility exceeded $70 \%$ for phenols and $60 \%$ in flavonoids. The whole fruit extract of xoconostle is a natural option to control the released glucose level by inhibition of carbohydrate hydrolyzing enzymes $\alpha$-amylase and $\alpha$-glucosidase. The inhibitory effects of both enzymes keep going after simulated intestinal conditions. The extracts of xoconostle have compounds that inhibition enzymes relate with antidiabetic activity, and they have the potential to be used as nutraceutical compounds.

Author Contributions: Writing—original draft preparation G.M.-P.; Investigation A.K.Z.-O., M.; Writing—review and editing A.-d.J.C.-G.; Formal analysis L.N.A.-B.; Validation R.V.-A.; Methodology J.A.E.-D.; Data curation R.G.C.-M.

Funding: This research received no external funding.

Conflicts of Interest: The authors declare no conflict of interest.

\section{References}

1. Zheng, Y.; Ley, S.H.; Hu, F.B. Global aetiology and epidemiology of type 2 diabetes mellitus and its complications. Nat. Rev. Endocrinol. 2018, 14, 88. [CrossRef]

2. Bonora, E. Postprandial peaks as a risk factor for cardiovascular disease: Epidemiological Perspectives. Int. J. Clin. Pract. Suppl. 2002, 129, 5-11. 
3. López-Romero, P.; Pichardo-Ontiveros, E.; Avila-Nava, A.; Vázquez-Manjarrez, N.; Tovar, A.R.; Pedraza-Chaverri, J.; Torres, N. The effect of nopal (Opuntia ficus indica) on postprandial blood glucose, incretins, and antioxidant activity in Mexican patients with type 2 diabetes after consumption of two different composition breakfasts. J. Acad. Nutr. Diet. 2014, 114, 1811-1818. [CrossRef]

4. Paiz, R.C.; Juárez-Flores, B.I.; Cecilia, J.R.A.R.N.; Ortega, C.; Aguuml, J.A.R.; Chávez, E.G.; Fuentes, G.Á. Glucose-lowering effect of xoconostle (Opuntia joconostle A. Web., Cactaceae) in diabetic rats. J. Med. Plants Res. 2010, 4, 2326-2333. [CrossRef]

5. Lordan, S.; Smyth, T.J.; Soler-Vila, A.; Stanton, C.; Ross, R.P. The $\alpha$-amylase and $\alpha$-glucosidase inhibitory effects of Irish seaweed extracts. Food Chem. 2013, 141, 2170-2176. [CrossRef] [PubMed]

6. Kwon, Y.I.; Apostolidis, E.; Shetty, K. Evaluation of pepper (Capsicum annuum) for management of diabetes and hypertension. J. Food Biochem. 2007, 31, 370-385. [CrossRef]

7. Gondi, M.; Rao, U.P. Ethanol extract of mango (Mangifera indica L.) peel inhibits $\alpha$-amylase and $\alpha$-glucosidase activities, and ameliorates diabetes related biochemical parameters in streptozotocin (STZ)-induced diabetic rats. J. Food Sci. Technol. 2015, 52, 7883-7893. [CrossRef]

8. Kazeem, M.; Adamson, J.; Ogunwande, I. Modes of inhibition of $\alpha$-amylase and $\alpha$-glucosidase by aqueous extract of Morinda lucida Benth leaf. BioMed Res. Int. 2013, 2013, 52757. [CrossRef] [PubMed]

9. Dra, L.A.; Rodrigues, M.J.; da Rosa Neng, N.; Nogueira, J.M.; Elamine, Y.; Aghraz, A.; Markouk, M.; Larhsini, M.; Custódio, L. Exploring Caralluma europaea (Guss.) NE Br. as a potential source of bioactive molecules: In vitro antioxidant and antidiabetic properties, and phenolic profile of crude extracts and fractions. Ind. Crop Prod. 2019, 139, 111527. [CrossRef]

10. Stintzing, F.C.; Carle, R. Cactus stems (Opuntia spp.): A review on their chemistry, technology, and uses. Mol. Nutr. Food Res. 2005, 49, 175-194. [CrossRef] [PubMed]

11. Pimienta-Barrios, E.; Méndez-Morán, L.; Ramírez-Hernández, B.C.; García de Alba-García, J.E.; Domínguez-Arias, R.M. Efecto de la ingestión del fruto de xoconostle (Opuntia joconostle Web.) sobre la glucosa y lípidos séricos. Agrociencia 2008, 42, 645-653.

12. Hernández-Fuentes, A.D.; Trapala-Islas, A.; Gallegos-Vásquez, C.; Campos-Montiel, R.G.; Pinedo-Espinoza, J.M.; Guzmán-Maldonado, S.H. Physicochemical variability and nutritional and functional characteristics of xoconostles (Opuntia spp.) accessions from Mexico. Fruits 2015, 70, 109-116. [CrossRef]

13. Yin, Z.; Zhang, W.; Feng, F.; Zhang, Y.; Kang, W. $\alpha$-Glucosidase inhibitors isolated from medicinal plants. Food Sci. Hum. Wellness 2014, 3, 136-174. [CrossRef]

14. $\mathrm{Xu}, \mathrm{H}$. Inhibition kinetics of flavonoids on yeast $\alpha$-glucosidase merged with docking simulations. Protein Peptide Lett. 2010, 17, 1270-1279. [CrossRef] [PubMed]

15. Peng, X.; Zhang, G.; Liao, Y.; Gong, D. Inhibitory kinetics and mechanism of kaempferol on $\alpha$-glucosidase. Food Chem. 2016, 190, 207-215. [CrossRef]

16. Hur, S.J.; Lim, B.O.; Decker, E.A.; McClements, D.J. In vitro human digestion models for food applications. Food Chem. 2011, 125, 1-12. [CrossRef]

17. Osorio-Esquivel, O.; Álvarez, V.B.; Dorantes-Álvarez, L.; Giusti, M.M. Phenolics betacyanins and antioxidant activity in Opuntia joconostle fruits. Food Res. Int. 2011, 44, 2160-2168. [CrossRef]

18. Espinosa-Muñoz, V.; Roldán-cruz, C.; Hernández-Fuentes, A.; Quintero-Lira, A.; Almaraz-Buendía, I.; Campos-Montiel, R. Ultrasonic-Assisted Extraction of Phenols, Flavonoids, and Biocompounds with Inhibitory Effect Against Salmonella Typhimurium and Staphylococcus Aureus from Cactus Pear. J. Food Process Eng. 2017, 40, e12358. [CrossRef]

19. Abirami, A.; Nagarani, G.; Siddhuraju, P. In Vitro antioxidant, anti-diabetic, cholinesterase and tyrosinase inhibitory potential of fresh juice from Citrus hystrix and C. maxima fruits. Food Sci. Hum. Wellness 2014, 3, 16-25. [CrossRef]

20. Pradeep, P.M.; Sreerama, Y.N. Phenolic antioxidants of foxtail and little millet cultivars and their inhibitory effects on $\alpha$-amylase and $\alpha$-glucosidase activities. Food Chem. 2018, 247, 46-55. [CrossRef]

21. Ames, J.M.; Wynne, A.; Hofmann, A.; Plos, S.; Gibson, G.R. The effect of a model melanoidin mixture on faecal bacterial populations in vitro. Br. J. Nutr. 1999, 82, 489-495. [CrossRef] [PubMed]

22. Guzmán-Maldonado, S.H.; Morales-Montelongo, A.L.; Mondragón-Jacobo, C.; Herrera-Hernández, G.; Guevara-Lara, F.; Reynoso-Camacho, R. Physicochemical, Nutritional, and functional characterization of fruits xoconostle (Opuntia matudae) pears from central-México region. J. Food Sci. 2010, 75, 485-492. [CrossRef] [PubMed] 
23. Morales, P.; Ramírez-Moreno, E.; de Cortes Sanchez-Mata, M.; Carvalho, A.M.; Ferreira, I.C. Nutritional and antioxidant properties of pulp and seeds of two xoconostle cultivars (Opuntia joconostle FAC Weber ex Diguet and Opuntia matudae Scheinvar) of high consumption in Mexico. Food Res. Int. 2012, 46, 279-285. [CrossRef]

24. Quiñones, M.; Miguel, M.; Aleixandre, A. Los polifenoles, compuestos de origen natural con efectos saludables sobre el sistema cardiovascular. Nutr. Hosp. 2012, 27, 76-89. [CrossRef] [PubMed]

25. Uddin, N.; Hasan, M.R.; Hossain, M.M.; Sarker, A.; Hasan, A.H.; Islam, A.F.; Chowdhury, M.M.; Rana, M.S. In vitro $\alpha$-amylase inhibitory activity and in vivo hypoglycemic effect of methanol extract of Citrus macroptera Montr. fruit. Asian Pac. J. Trop. Biomed. 2014, 4, 473-479. [CrossRef]

26. Wang, Z.C.; Tanzeela, N.; Sun, L.J.; Fang, Z.X.; Yan, Y.Z.; Li, D.; Xie, H.C.; Wang, H.C.; Guo, Y.R. Effect of in vitro gastrointestinal digestion on the composition and bioactivity of anthocyanins in the fruits of cultivated Lycium ruthenicum Murray. CYTA-J. Food 2019, 17, 552-562. [CrossRef]

27. Funke, I.; Melzig, M.F. Traditionally used plants in diabetes therapy: Phytotherapeutics as inhibitors of alpha-amylase activity. Rev. Bras. Farmacogn. 2006, 16, 1-5. [CrossRef]

28. Pinto, M.D.S.; Ranilla, L.G.; Apostolidis, E.; Lajolo, F.M.; Genovese, M.I.; Shetty, K. Evaluation of antihyperglycemia and antihypertension potential of native Peruvian fruits using in vitro models. J. Med. Food 2009, 12, 278-291. [CrossRef] [PubMed]

29. Liu, Z.G.; Dang, J.; Wang, Q.L.; Yu, M.F.; Jiang, L.; Mei, L.J.; Shao, Y.; Tao, Y.D. Optimization of polysaccharides from Lycium ruthenicum fruit using RSM and its anti-oxidant activity. Int. J. Biol. Macromol. 2013, 61, 127-134. [CrossRef] [PubMed]

30. Ghosh, S.; Ahire, M.; Patil, S.; Jabgunde, A.; Bhat Dusane, M.; Joshi, B.N.; Pardesi, K.; Jachak, S.; Dhavale, D.D.; Chopade, B.A. Antidiabetic activity of Gnidia glauca and Dioscorea bulbifera: Potent amylase and glucosidase inhibitors. Evid. Based Complement. Alternat. Med. 2012, 2012, 929051. [CrossRef] [PubMed]

31. López-Martínez, L.X.; Aguilar Cisneros, L.M.; Dublán-García, O. Actividad antioxidante e inhibidora de $\alpha$-glucosidasa y $\alpha$-amilasa de tres variedades de cebolla (Allium cepa L.). Nova Scientia 2014, 6, $234-347$. [CrossRef]

32. Mendoza Meza, D.L.; Medina Valdés, R. Inhibición in vitro de las enzimas alfa-amilasa y lipasa pancreática por fracciones fenólicas de extractos etanólicos de hojas de Yacón (Smallanthus sonchifolius Poepp. \& Endl). Avances en Química 2015, 10, 33-40.

33. Hemalatha, P.; Bomzan, D.P.; Rao, B.S.; Sreerama, Y.N. Distribution of phenolic antioxidants in whole and milled fractions of quinoa and their inhibitory effects on $\alpha$-amylase and $\alpha$-glucosidase activities. Food Chem. 2016, 199, 330-338. [CrossRef] [PubMed]

34. Apostolidis, E.; Karayannakidis, P.D.; Kwon, Y.-I.; Lee, C.M.; Seeram, N.P. Seasonal variation of phenolic antioxidant-mediated $\alpha$-glucosidase inhibition of Ascophyllum nodosum. Plant Food Hum. Nutr. 2011, 66, 313-319. [CrossRef] [PubMed]

35. Cenobio-Galindo, A.; Pimentel-González, D.J.; Del Razo-Rodríguez, O.E.; Medina-Pérez, G.; Carrillo-Inungaray, M.L.; Reyes-Munguía, A.; Campos-Montiel, R.G. Antioxidant and antibacterial activities of a starch film with bioextracts microencapsulated from cactus fruits (Opuntia oligacantha). Food Sci. Biotechnol. 2019, 28, 1-9. [CrossRef]

36. Bouayed, J.; Deußer, H.; Hoffmann, L.; Bohn, T. Bioaccessible and dialysable polyphenols in selected apple varieties following in vitro digestion vs. their native patterns. Food Chem. 2012, 131, 1466-1472. [CrossRef]

37. Spínola, V.; Pinto, J.; Llorent-Martínez, E.J.; Castilho, P.C. Changes in the phenolic compositions of Elaeagnus umbellata and Sambucus lanceolata after in vitro gastrointestinal digestion and evaluation of their potential anti-diabetic properties. Food Res. Int. 2019, 122, 283-294. [CrossRef]

38. Vallejo, F.; Gil-Izquierdo, A.; Pérez-Vicente, A.; García-Viguera, C. In vitro gastrointestinal digestion study of broccoli inflorescence phenolic compounds, glucosinolates, and vitamin C. J. Agric. Food Chem. 2004, 52, 135-138. [CrossRef]

39. McDougall, G.J.; Shpiro, F.; Dobson, P.; Smith, P.; Blake, A.; Stewart, D. Different polyphenolic components of soft fruits inhibit $\alpha$-amylase and $\alpha$-glucosidase. J. Agric. Food Chem. 2005, 53, 2760-2766. [CrossRef]

(C) 2019 by the authors. Licensee MDPI, Basel, Switzerland. This article is an open access article distributed under the terms and conditions of the Creative Commons Attribution (CC BY) license (http://creativecommons.org/licenses/by/4.0/). 